\title{
Transformative climate adaptation in the United States: Trends and prospects
}

\author{
Linda Shi ${ }^{*}$ and Susanne Moser ${ }^{2,3}$ \\ 1Department of City and Regional Planning, Cornell University, 213 West Sibley Hall, Ithaca, NY 14853, USA. 2Susanne Moser Research and Consulting, Hadley, MA 01035, \\ USA. ${ }^{3}$ Department of Landscape Architecture and Regional Planning, University of Massachusetts-Amherst, Amherst, MA, 01002, USA. \\ *Corresponding author. Email: lindashi@cornell.edu \\ As climate change intensifies, civil society is increasingly calling for transformative adaptation that \\ redresses drivers of climate vulnerability. We review trends in how U.S. federal government, private \\ industry and civil society are planning for climate adaptation. We find growing divergence in their \\ approaches and impacts. This incoherence increases maladaptive investment in climate-blind \\ infrastructure, justice-blind reforms in financial and professional sectors, and greater societal vulnerability \\ to climate impacts. If these actors were to proactively and deliberatively engage in transformative \\ adaptation, they would need to address the material, relational and normative factors that hold current \\ systems in place. Drawing on a review of transformation and collective impact literatures, we conclude with \\ directions for research and policy engagement to support more transformative adaptation moving forward.
}

Climate disasters are on the rise, with devastating effects on communities, built infrastructure and ecosystems. From wildfires in California to unprecedented floods in the Midwest, hurricanes affecting the Carolinas, Florida, Texas, Puerto Rico and more, no corner of the United States is left unscathed (1). These events and their costly impacts are blind to political affiliation and jurisdictional boundaries, although they have the greatest consequences for disadvantaged groups who already struggle with poverty and marginalization (I). Even before the COVID-19 pandemic and resulting socio-economic crisis, communities were inadequately prepared for emerging climate impacts. Recent events, however, have laid bare the U.S.'s systemic vulnerabilities and constraints in launching large-scale, coordinated, equitable and effective responses to external shocks, resulting in severe disruptions and prolonged crises (2). Existing challenges, chronic underfunding, subsequent short-sightedness and ineffective government coordination - exacerbated by partisan politics and lack of consistent federal leadership - have hobbled state and local governments' ability to mount effective responses $(3,4)$.

The Biden administration has taken bold steps toward leadership on climate change, raising hopes again that the log jam of action may finally be broken, bringing renewed focus on climate mitigation and adaptation. Biden's early climate initiatives indicate a transformative push for decarbonization, but visioning documents and plans say little about the strategy for climate resilience. Proposals for a multi-trillion-dollar infrastructure package would provide an influx of cash for local and state governments, but the desire for an "infrastructure fix" may be misguided, illusory, or simply inadequate. To date, no individual has been named to be the leading force on adaptation in the new administration, and it is reasonable to ask whether federal climate adaptation leadership in the intellectual and political footsteps of the Obama Administration adequately addresses the challenges facing U.S. communities.

In this paper, we review major federal policy changes, industry actions and civil discourses on climate adaptation and how divergent societal trends inhibit efficient, effective and fair adaptation to climate impacts on the ground. We examine these trends through a transformation lens and - more specifically - through insights from the collective impact literature on factors that hold systems in place (5-7). Drawing on the growing body of literature that critiques existing adaptation practices as inadequate, uncoordinated and unjust, we examine the extent to which the sectoral trends reflect changes in policies, practices, resource flows, social relations, power dynamics and underlying mindsets. We find that while there have been significant shifts since the end of the Obama Administration, they do not converge toward deliberative, purposive and just adaptation. As the 2020 U.S. election underscores, a change in the White House clearly establishes a new direction but Congressional partisanship, societal divisions and structural and normative barriers challenge fundamental shifts in societal adaptation across the United States. This suggests that transformative adaptation requires tackling historical legacies and societal engagement. 


\section{tion \\ The imperative for transformative climate adapta-}

The frequency, severity and costs of climate change are rapidly increasing. Between 2015 and 2020, the U.S. has seen an average of 14 disasters per year that cost at least one billion dollars, compared to 6.5 such events annually between 1980 and 2019 (8). The Fourth National Climate Assessment (2018) details how climate change has contributed to and will exacerbate the frequency and intensity of acute and longterm disaster trends (1). For example, over $\$ 1$ trillion of coastal real estate and 13.1 million people are threatened by rising sea levels, higher storm surges and higher tidal flooding (I). Under current emissions trends, $\$ 66$ to $\$ 106$ billion of real estate will highly likely be below sea level by 2050 , i.e., one mortgage cycle away (1). Left unaddressed, failing infrastructure systems will reduce GDP by $\$ 3.9$ trillion within just five years, roughly $20 \%$ of current GDP (9). Currently debated infrastructure solutions are costly and already beyond reach for many communities, incentivize continued development in hazardous locations, protect against only low to moderate levels of climate impacts and are inequitably distributed across communities $(10,11)$. Practitioners and the media now openly discuss large-scale relocation due to climate change, even while recognizing that climate is one among many social, economic, political and environmental factors driving migration choices (12-15).

Past experience with climate impacts and the COVID-19 crisis illustrate how hazard impacts fall disproportionately on the most vulnerable populations, i.e., those structurally disadvantaged due to race, income or other identity markers in access to housing, jobs, basic services and political voice in planning and decision-making (1). Moreover, teleconnected, compounding and cascading risks increase exposure and vulnerability (16), reduce adaptive capacity (by eroding funding, diminishing staff capacity, leaving fewer options) and contribute to erosive cycles of social trauma and economic decline $(3,17,18)$. Without funding to shore-up protective infrastructure or investments in water, food, energy, healthcare and other systems, communities will experience unmitigated climate impacts sooner than expected, with knock-on impacts to local economies and community wellbeing (19). Without systemic policies, communities will experience - and be left on their own to navigate - displacement, unaffordable and insufficient housing markets, and declining economies and regions (20).

Growing civic discourse and bodies of research advocate for transformative adaptation that redresses the underlying drivers of societal vulnerability to climate change (21-24). The complexity and magnitude of the current multi-stressor crisis (health, economic, climate and racism) illustrate that incremental efforts "aimed at accommodating change, rather than contesting it" (25) no longer suffice. While dominant approaches to adaptation address "end-point vulnerability" (i.e., the most visible symptoms of past development patterns, societal relations and human-environment interactions), transformative adaptation responds to "starting-point vulnerability" (i.e., the deep roots and conditions producing vulnerability in the first place) (26). Transformative adaptation, as a relatively new concept, is still being explored and awaits widespread application in practice. It may include changing economic paradigms and development patterns away from those predicated on the exploitation of nature without limits; redressing systemic racism, imperialism and misogyny; decolonizing of knowledge systems; reforming governance institutions that operationalize these developmental logics; and reckoning with underlying worldviews and values that legitimize dominance and exceptionalism.

In short, transformative adaptation is not just about "climate-proofing" existing structures and systems, but about deliberately and fundamentally changing systems to achieve more just and equitable adaptation outcomes (27). This implies investigating the factors that maintain the status quo and strategically addressing them to intentionally shift systems in new directions.

\section{Key factors in changing systems: A theoretical lens}

Figure 1 shows six fundamental factors that keep systems in place: at the surface level, policies, practices and resource flows are determined at a deeper level by the processes, relationships and power dynamics among those making decisions, which in turn is a reflection of the mindsets, values and beliefs of those involved. The depiction implies the type and depth of change (notations on the left side of the triangle) and points to the needs and requirements to deeply transform systems, linked to a series of leverage points (on the right side) to address them. Large, multiscalar and multisystem coordination and reform to adaptation policies, practices and resource flows would change the structural and material aspects of systems. However, as critics of the "resilience dividend" (28) and "disaster capitalism", and climate-centered movements for a Green New Deal and Extinction Rebellion (in the UK) have argued $(29,30)$, large-scale change can seek to preserve the status quo unless reforms change the underlying social relationships and power dynamics and center a different set of values and beliefs about humans and humannature relations.

This conceptual framework of transformation (31) provides a basis for assessing the implications of how the major sectors of U.S. society - public, private, civil - are reacting to climate impacts. What changes at the level of policies, practices and resource flows do they espouse with respect to climate adaptation? What power dynamics and relationships do these actions reflect? What mindsets and values inform these relationships and power dynamics? Who and what is valued 
more or less? How do they need to change to affect decisions and the direction of actions taken toward more just adaptation? What deeply held assumptions underlie adaptation decision-making processes and what prevents them from changing?

Below, we review three trends that illustrate how and why emerging adaptation practices neither respond to the transformation imperative nor converge toward the necessary changes in the six factors that hold systems in place. The result is what can be observed across the U.S. at present: delayed, uncoordinated and potentially ineffective or even maladaptive response to growing climate risks. Aligning the key actors for positive transformative change will require attending not only to the top-level structural and material aspects of adaptation (itself no easy task) but to the social relations, processes and mindset changes necessary to achieve deeper transformational outcomes (32).

\section{Recent trends in U.S. adaptation \\ Trend 1: Federal restraint in and retreat from cli- mate adaptation policy}

Federal engagement with climate adaptation has been mixed. The Obama Administration initiated adaptation policies in its second term, which the Trump Administration actively revoked. The Biden Administration has promised to embed climate resilience into diverse administrative efforts, to be carried out by mission agencies (e.g., reinstating Obama's flood standards). To date, however, there has been no consistent or comprehensive approach to adaptation policymaking and limited federal funding support across all three administrations, resulting in a widening gap between levels of government and fragmented responses across jurisdictions. The tasks and costs of recovering from disasters have strained the fiscal, administrative and response capacities of the Federal Emergency Management Agency (FEMA) and state and local governments, whose existing programs and funds are far outstripped by the scale of climate impacts and needs $(33,34)$. Moreover, beyond surface level policy retreat or inconsistency, the federal government has consistently shown little support for national-level visioning on climate adaptation, justice-oriented adaptation planning and governance reform, while increasing partisanship has hampered its ability to address societal vulnerability to changing land, infrastructure and health conditions under climate change.

The federal government recognizes its climate risks as a major owner and operator of infrastructure, facilities, military installations, natural and working lands, and insurer of properties and crops $(35,36)$ yet, for years, it has lacked a comprehensive approach to assessing and disclosing the vulnerability of federal assets and programs, much less planning for their adaptation, leaving states, localities and individual agencies to make their own plans $(37,38)$. Recognizing that leadership came from outside the federal government, the Obama Administration formed a State, Local and Tribal Leaders Task Force on Climate Preparedness and Resilience in 2014 (39). Following their recommendations, the Administration issued a series of executive orders (Table 1) requiring federal agencies to consider climate risks in their policies, practices, investments and programs (using the federally mandated National Climate Assessments); to coordinate among themselves and with other levels of government; issue plans; and to train staff $(36,40)$.

The Trump Administration rolled back these efforts by revoking each of Obama's executive orders (Table 1). Budget cuts to the Environmental Protection Agency (EPA) and National Oceanographic and Atmospheric Administration (NOAA), as well as erasure of climate data on NOAA's portal, have reduced the federal government's capacity to meet state and local governments' technical data needs. A 2019 Government Accountability Office (GAO) report found that the federal government has done nothing to reduce its high fiscal risk exposure due to climate change (41). Moreover, federal responses are inconsistent across agencies: the 2019 Department of Homeland Security's National Preparedness Report does not mention "climate change" or "sea-level rise" (or pandemics, for that matter) (42) yet the U.S. Army Corps of Engineers (USACE) has begun to require localities receiving federal disaster assistance to use eminent domain to force reluctant homeowners from repeatedly flooded homes. This controversial application of eminent domain signals USACE's and FEMA's awareness of the urgent and worsening nature of flood impacts (43). While reducing federal disaster recovery costs, such measures overlook how flood insurance and local land use fiscalization incentivize floodplain development and how relocation without accompanying housing and fiscal reforms can harm households and municipal coffers.

Where federal agencies do plan for adaptation, the focus has been on "climate proofing" physical infrastructure without considering land use policies and development paradigms driving inequitable and unsustainable development. Under the Obama Administration, federal action on adaptation accelerated after Hurricane Sandy in 2012. Federal, state and local alignment on climate-resilient reconstruction, especially in New York State, enabled more effective recovery (44). However, to secure Congressional support for the region's reconstruction and other climate projects, the Obama Administration framed adaptation as disaster resilience, infrastructure investment and national security rather than addressing the drivers of vulnerability and the need for systemic transformation (40). Politically sensitive issues such as housing and tax policy, food security, land inequality, rural and indigenous resource extraction, or long-term national and regional spatial planning have not been part of the 
national adaptation conversation. The Biden Administration has demonstrated commitment to environmental justice and investment in wide-ranging social welfare programs, but specific climate policies have focused primarily on decarbonization. Attention to resilience is taking the form of infrastructure funding and connecting climate change to international migration - evidence that the Administration's approach echoes policies of the Obama era.

While the Trump Administration's retreat on adaptation leadership has cost precious time, the possibly even more concerning legacy is the political polarization at the federal level that challenges science-based problem-solving and policymaking across partisan divides. The proposed Green New Deal (GND) connects decarbonization and clean energy to social justice issues of health care, wages and housing $(45,46)$. The approach remains embedded within the current economic development model but stresses redistribution to enable equitable development. While attempts are underway to implement elements of the GND piecemeal, continued Congressional partisanship raises questions about whether cooperative policy engagement will be possible (47), even if younger Republicans recognize the need for climate solutions and support some of the policies endorsed by the GND (48). Private industry shifts may open political doors and offer opportunities for pragmatic advances on climate action.

Trend 2: Industry reforms in practices and standards governing risk and liability

Standard-setting organizations overseeing engineering, design, insurance and lending practices are moving toward incorporating climate science into their benchmarks, requirements and guidelines. This reflects a growing concern with managing their own legal and financial liability risks, including the failure to anticipate climate impacts within project life cycles under "standards of care" expectations (49-51). Industry-led adjustments place growing pressures on state and local governments to act on climate adaptation. Against the backdrop of recent federal reversals, these shifts create significant confusion of competing standards. Governments and their employees could themselves become liable for failing to anticipate climate impacts during the lifespan of projects in this era of nebulous and uncharted legal waters (51). Moreover, state and local fallout from these policy shifts may also increase demands on federal investments and aid (52).

Housing markets also are beginning to account for climate impacts, although there continues to be a spatial mismatch between real estate values and property risk (53). Recent research finds that, nationally, exposure to sea-level rise, flooding and higher insurance premiums is beginning to have a negative impact on property values (54-56). Calls to reform the National Flood Insurance Program - e.g., through better maps of future flood risk under climate change, disclosure agreements during property transactions, streamlined and expanded buyout programs, shifting from individual to community flood insurance, actuarial risk pricing and addressing affordability and retention issues $(57,58)$ - accelerate market internalization of climate risk. In the absence of federal leadership on risk disclosure, private consulting firms (and some NGOs) are growing their in-house technical expertise to map forward-looking flood risks, informing not only individual homeowner purchasing decisions but, implicitly, the real estate market $(58,59)$. These private-sector shifts impact property values, which can negatively impact individual households' primary asset as well as municipal tax rolls and locally-funded services (11).

Globally, financial institutions - including public and private banks, insurance companies and bond rating agencies understand the shifting landscapes of market risk and are engaged in an "intelligence arms race" to measure climate impacts on investments and steer them to new speculative sites and cities (60). A network of central and public banks outside the U.S. is defining assets as "green" or "brown" according to their carbon emissions and climate risks. In tandem, the global Task Force on Climate-Related Financial Disclosures has tasked its 800-plus member public and private organizations holding $\$ 118$ trillion in assets to disclose their climate risks (61). Domestically, bond rating agencies like Standard \& Poor's and Moody's are starting to incorporate climate mitigation and preparedness measures into municipal bond ratings $(62,63)$.

Finally, international and national associations of engineers are working to provide guidance on how to integrate forward-looking climate science into design guidelines, engineering standards and standards of care. In 2015, the World Federation of Engineering Organizations issued a report, "Model Code of Practice: Principles of Climate Change Adaptation for Engineers" as guidance for voluntary adoption by individuals and nations (64). Canada is incorporating climate impacts into its national building code and in 2018 the American Society of Civil Engineers (ASCE) Committee on Adaptation to a Changing Climate released a manual on incorporating forward-looking climate science into engineering design (65) and is working on a standard to further codify climate-sensitive engineering.

These reforms highlight the private sector's recognition of the reality of climate change. They also point to industry's agility in large-scale responses, even if they are not (yet) deviating from historic processes of unequal development or the underlying worldviews and paradigmatic commitments. Industry is far more rapidly learning about climate impacts; buying or investing in new modeling techniques to identify risk, liability and potential "Climate Oases" (see http://futuremap.io/climateoases) (60); and forming committees and taskforces to systematize standards across large networks. As 
such, they represent a welcome, constructive shift in who joins and what is being discussed at the climate action table. However, these efforts still prioritize corporate investments and liability (i.e., profitability), rather than human wellbeing or the inherent rights of nature (66). Contemporary observers see the financialization of climate risks presenting new sacrifice zones predicated on race (66), for instance by funding speculative investment in a Resilient Rustbelt or by refusing to lend in "bluelined" low-lying areas just like banks once refused to lend in "redlined" black neighborhoods (67). While disasters threaten to destabilize the insurance industry, insurers also thrive on disasters, which swell demand for new policies (68). Municipalities that lose tax revenues from property devaluation may face growing difficulty maintaining bond ratings and/or repaying more expensive bonds, further destabilizing local service provision in a vicious cycle $(11,69)$. While some cities may use climate resilience discourse to market their competitiveness (70) or benefit from shifting standards, the decline of "climate slums" in other municipalities contribute to new intra- and inter-municipal inequality (71). In other words, the private sector's engagement on adaptation is not oriented toward societal well-being or reparative justice for the historically disadvantaged.

\section{Trend 3: Academic and community-based advocacy oftransformative adaptation}

Against the backdrop of lagging federal leadership, corporatization of climate action and the increasingly pressing threats of climate change impacting communities, mobilization from the bottom-up is a third notable trend. Civil society groups increasingly contest mainstream adaptation efforts as inadequately protecting historically marginalized communities - whether through "acts of commission" or "omission" (77). For instance, the neighborhoods where Philadelphia expanded household green infrastructure to absorb stormwater saw the highest levels of gentrification (72). In Houston, historically Black communities that have long been neglected for drainage improvements were targeted for FEMA property buyouts after Hurricane Harvey using eminent domain, while similarly impacted but wealthier and whiter communities were offered FEMA home renovation and elevation funding (73). In South Florida, historically disadvantaged Black and Haitian communities on higher elevations are being targeted for speculative development as markets slowly begin to penalize coastal condos (74). Additionally, whereas five years ago practitioners noted that "re" words (such as retreat, relocation and resettlement) were forbidden, now there are conferences like Columbia University's "At What Point Managed Retreat?", planning for whole-community (albeit not yet whole-city) resettlement (e.g., in Louisiana and Alaska), and websites and initiatives devoted to "Climigration" (75, 76). Critical discourses of past redlining, buy-out and relocation approaches are emerging, questioning not only administrative inadequacies, but the fundamental inequities besetting conventional technocratic approaches to relocation, both for "sending communities" and "receiving communities" in nearcoastal and interior cities $(13,14)$.

In response, community-based groups are proposing alternative pathways forward $(77,78)$. They have articulated new proposals for equitable and just adaptation (81) that emphasize recognition of historic racism and oppression, demand solidarity and diverse and inclusive leadership, and uplift holistic visions of what it takes to create a safer, thriving society (78). They center opposition to racism and structural drivers of inequality, and as such focus first on deep mindset and relational/power issues as foundations of policy, practice and resource flow.

In parallel, a growing body of academic research demonstrates the oppressiveness and ineffectiveness of ongoing adaptation and so-called resiliency strategies that recapitulate historic exclusionary, extractive and racist or classist policies (79-82). Research shows that vulnerability to natural hazards stem not only from the probability of risk, or even individual sensitivity due to disability, age, poverty or linguistic isolation. Rather, vulnerability results from historic centralization of political power, land and resources; dispossession of communities from rural self-sufficiency and concentration of people in urban areas as productive workers and consumers; unequally allocation of land, housing, environmental goods (e.g., clean air, water, parks); and - through voter disenfranchisement and divisive politics - sustaining a disadvantaged class that enables the social reproduction of this political economic system (83-85). Vulnerability assessments and resource allocations that consider only present-day variations in flood risk deny the impact of historic oppression and trauma, such as redlining and urban renewal; forced relocation of Native Americans and denial of their kinship ties and lifeways; exposure to toxic pollutants, particulate matter and environmental extremes; and infrastructure and service provision $(86,87)$.

Alternative visions of societal well-being have emerged from different groups, finding solidarity across race, gender, urban-rural divides and building coalitions across issues. This is changing social relations and helps bring greater power against entrenched interests. Both researchers and community activists in this way have pushed local governments to recognize the relational and historic nature of present-day uneven vulnerability as a first step toward more just practices $(78,88)$. While some local adaptation plans now include language on participation and inclusion of disadvantaged communities in planning processes (89), community organizers go much farther by calling for building community leadership capacity and social movement infrastructure, 
forming coalitions and partnerships, and gaining elected office or decision-making power $(78,90)$.

In an attempt to scale up such local efforts, Climate Justice Alternatives, a group of 65-plus frontline and movement building organizations and networks across the country, has articulated a framework for "Just Transition" (91). This framework advocates a paradigm shift away from an extractive economy predicated on "global plunder, the profit-driven industrial economy rooted in patriarchy and white supremacy" to a regenerative economy that focuses on "redressing past harms and creating new relationships of power for the future through reparations" (91). This non-Euro-centric leadership model emphasizes alternative values and development possibilities, such as buen vivir, consent, trust, accountability, respect, reciprocity and responsibility (101-103).

\section{Prospects of transformative adaptation}

These three trends can be distilled as federal retreat or stalling on comprehensive adaptation policy and support, private-sector engagement reinforcing existing economic paradigms and interests, and civil society critique, resistance, and movement building for transformative adaptation. The divergence among these actors makes clear that a shift in presidential leadership alone cannot shift the politics, power dynamics, and paradigms that shape adaptation in the United States. If public, private and civil society actors were to take up the transformation imperative in a proactive and deliberate way, the six factors that hold systems in place would need to be addressed. Both scholarship and practice suggest how this might occur at the level of the material, relational and normative (Fig. 1).

The following sections reflect on ways to redress underlying drivers of vulnerability and align conflicting discourses at each of these three levels of transformation. Figure 2 visualizes these ideas. The diagram recognizes the need to adapt to changing geophysical climate conditions (yellow arrow) but roots the causal conditions in historic social, political, and economic drivers of vulnerability (grey arrow). The middle ring of the diagram comprises strategies to transform adaptation normatively (by asserting values of recognition, justice, equity, and inclusion, in red), procedurally (through empowered and deliberative practices, in green), and materially (through large-scale, systemic thinking, in orange). The diagram's inner wheel points out the need to embed adaptation's normative values, processes, and policies throughout the sectors shaping the country's physical and social well-being. This approach seeks to break through partisan divides by creating opportunities to reflect on shared traumas, shared values, and mutual interdependence of communities across the urban and rural landscape in grappling with the challenge of climate change.
Large-scale, systemic thinking in shaping policies, practices and resource flows

Effective change must address large geographic scales and connections across scales, and account for individual localities as embedded units within territorial landscapes of regions, urban-rural gradients and natural ecosystems $(94,95)$. Traditional hazard assessments and adaptation planning focus narrowly on single cities, hazards, or sectors $(16,96,97)$, despite the interconnectedness of landscapes, infrastructure, markets and political systems. Instead, all governments need to assess and reduce their structural and material vulnerabilities to long-distance risks, compound impacts and cascading failures, as well as engage in multilevel coordination (3, 98, 99). Ambitious strategies such as a GND would put money toward infrastructure and new technologies, accelerate industrial and market shifts and expand the sites where such technologies are available and adopted. New emphasis on nature-based solutions for flood risk reduction may also transform engineering and infrastructure operating practices (100-102). However, the large-scale adoption of new technologies alone does not challenge historic drivers of income, housing and land inequality, the extractive nature of industrial development and urbanization, or the need to for more dynamic and agile solutions in place of static infrastructure projects. Systemic policies like the GND need to explicitly address these to change high-level policy guidance, practices and resource flows $(103,104)$.

\section{Emporerment and deliberative processes}

Any effort to transform the structural and material dimensions of systems necessitates transforming the relationships and power dynamics among actors, as well as their ability to lead inclusively during turbulent times $(21,25,105)$. Within the adaptation context, scholars and activists have called for changes in public engagement processes, as well as more transparent and accessible decision-making procedures, so that stakeholders' and rightsholders' concerns and needs have a better chance of being heard $(72,106,107)$. They claim that more democratic and inclusive processes are more likely to address stakeholders' concerns, particularly around equity and justice $(108,109)$. In addition, changing power structures by changing who is at the table of deliberative processes, whose voices get heard, who holds leadership positions and who has the real political power to make adaptation decisions is essential to changing course and addressing deep-seated vulnerabilities $(78,110)$.

As the election of 2020 demonstrates, winning elections alone does not eliminate the necessity of standing the difficult ground of principle while engaging in civil argument and education with those across the line of factual reality about racism, climate change and so on, to find a path toward collective problem solving. Deliberative and communicative 
planning research advocates processes that enable individual and community empowerment through learning, knowledge co-production, and personal and collective change (23). Deliberative, positively transformative adaptation - often community-led, better capacitated and politically-empowered would focus squarely on the procedural aspects and center the normative dimensions of adaptation.

\section{Asserting normative values of equity, justice and in- clusion}

Since large-scale, systemic change alone does not guarantee a desirable direction of change, scholars argue that transformative adaptation must normatively center justice in planning, infrastructure and governance reforms $(24,27)$. There is growing recognition that adaptation efforts without such a normative commitment can be maladaptive and worsen inequality $(77,111)$. Building a seawall in one area may increase flooding downcoast and gentrify existing neighborhoods, thereby offering some measure of protection to one enclave while transferring vulnerability to others $(77,97,112)$. Climate or green gentrification is already occurring where higher land elevations, climate-smart infrastructure upgrades, or nature-based solutions result in increased property values, taxes, or rents $(20,72)$. This can displace lower-income residents to more affordable places that confront new environmental risks $(20,72,113)$. Adaptive interventions can create other spillover effects that worsen conditions elsewhere (e.g., for low-income urban, suburban, or rural areas in the face of increasing competition over water, food and land resources (77)). Transformative adaptation reorients "climate actions around addressing entrenched equity and climate justice challenges. It [should focus] on systemic changes to development processes and [aim] at improving people's quality of life, enhancing the social and economic vibrancy of cities and ensuring sustainable, resilient and inclusive urban futures" (27).

\section{Science in support of transformative adaptation}

Whether it is a new Administration, a new Congress, relatively recent arrivals at the climate action table, or long-engaged implementers and observers of adaptation, critical questions must be asked at every turn regarding the material, relational and normative dimensions of transformative adaptation: Who do the changes in policies, practice or resource flows benefit? Will a strategy lead to a more equitable and just society, repairing historical systemic disadvantaging? Does a project, program or policy account not only for climate impacts but societal responses to these impacts in other sectors and geographies? Who is at the table? Whose claims and interests are heard and which kinds of knowledge count?

Conflicting notions of adaptation and the appropriate paths forward underscore the persistent disconnect between academic research and policy and practice. Almost all government funding on climate change to date has been in the natural and physical sciences (114). Unsurprisingly, there is limited knowledge still about basic aspects of societal adaptation, including how to support contentious communication and engagement about transformative adaptation, how to integrate indigenous or community-based knowledges with scientific knowledge and how this differs from integrating scientific knowledge with private-sector/business knowledge, how to navigate and change the power dynamics underlying the politics of decision-making, how to measure adaptation progress and "success" (for a bottom-up example, see http://www.resiliencemetrics.org) and, now, how to identify and track transformative adaptation and related social tipping points through meaningful indicators (104). The need to fund and support research on the intersections of coupled social-ecological-political systems, cascading impacts, vicious and virtuous cycles also persists.

At the level of power and deliberative processes, grassroots movements have focused on finding and building solidarity across racial minorities, middle-class predominantly white environmentalists and blue-collar workers. Some now also reach across rural-urban divide (e.g., Alliance for Appalachia, Farmworker Association of Florida, and Another Gulf is Possible). Community organizing strategies for solidarity and alliance-building offer powerful counterpoints to current partisan divisions at the federal and, increasingly, state levels (116). As researchers and pundits wring their hands about partisan divides and how to achieve aspirations for unity, these practices demonstrate an existing path toward solidarity, one that requires long years of sitting down, reaching across divides and building a different politics (including knowledge politics) from the ground up. Some of the critical questions here include: under what conditions have largescale reforms empowered democratic transformation? How can big data science help the social sciences in an ethical way to synthesize robust policy-relevant knowledge from the rich case study research base available? For instance, what are the necessary conditions that enable coalition building, social movements and effective institutionalization of knowledge? Conversations have begun about the skills, competencies and personal resilience of those working day-in and day-out on responding to climate change $(94,117-119)$, but what canon of leadership capacities, including psychosocial skills, is necessary for transformative change? What historic experiences inform how to rapidly develop and grow this new generation of leadership $(118,120)$ ?

On mindsets and values, while sectors fundamentally disagree on the normative values and purposes underlying societal adaptation, both science (121-123) and grassroots organizations have mounted powerful normative proposals for human flourishing on a resource-limited Earth. However, 
how to advance the necessary mindset and values shifts, how to affect deep cultural change, especially in increasingly existentially threatening conditions, is far from clear. If a regenerative economy is what people support, but the extractive economy is what we have, how can governance systems be destabilized and transitioned at a national scale, not just at a community and site scale? What are the necessary conditions connecting these changes across scales? How should existing spatial, fiscal and financial systems be reformed to promote justice? What engagement platforms are needed to enable reconciliation between community and industry viewpoints? What kinds of learning, dialogue and engagement foster transformative mindsets?

Finally, the slow processes of learning, values changes and trust-building that are implied in each of these areas of research ultimately raise a cross-cutting question for the scientific enterprise. A necessary fundamental change in the dynamics between researchers and practitioners, between white privileged and far-too-long marginalized communities (and their knowledge systems) points to the difficult-to-overcome tension between the urgency of climate impacts and proposed, large-scale solutions on the one hand and the time needed for deliberative processes, coalition and trust building, and the careful ethical considerations and reckoning with historical legacies required for transformation on the other (124). While the growing literature on transdisciplinarity has established how to work across traditional disciplinary and sectoral silos, the actual practice of engaged research is still not the dominant mode of scientific practice (125). Moreover, the literature has not grappled with the question of how to do "slow" engaged science that remains relevant to decision-making amidst accelerating environmental and social changes. This raises critical scientific, pragmatic and institutional questions about how to accelerate the necessary scientific work, the decision- and policy-making processes, and the interaction between both.

\section{Conclusion}

Forces of globalization, urbanization and climate change combined with the societal divisions that have always existed are bringing rapid, disorienting social and spatial changes. The persistent level of political stalemate in the U.S. reflects the scale of political, economic, social and geographic dislocation in recent decades. Adaptation responses to date have largely focused on maintaining existing systems, which have contributed to inequitable and unsustainable development, without addressing underlying drivers of vulnerability to climate impacts. Continuing with modestly adapting businessas-usual practices enables current holders of wealth and power to reduce their risks but leaves most residents illequipped for the far more dramatic changes ahead. Any effort to challenge long-established systems in favor of transformative shifts almost inevitably encounters politics of opposition, division and othering.

Transformative adaptation demands not only renewed Executive branch commitment to climate action but poses profound challenges to deliberative democracy, collective action, distributive justice and the science to support it. More than ever, a deeper understanding of transformation, illustrative examples and courageous leadership at all levels are necessary to change the pace, scale and depth of climate adaptation and the drivers of vulnerability that would move society to more just adaptation. This review points to how adaptation actors can stay at the table and constructively help shape what's on the table for transformative adaptation. It remains possible for all relevant actors to creatively and constructively engage more deeply on adaptation. In fact, the opportunity for demonstrating effective adaptive leadership under rapidly changing and ever more difficult circumstances has maybe never been greater.

\section{REFERENCES AND NOTES}

1. D. Easterling, K. Kunkel, K. Lewis, D. Reidmiller, B. Stewart, Eds., Impacts, Risks, and Adaptation in the United States: Fourth National Climate Assessment, Volume II: Report-in-Brief (U.S. Global Change Research Program, 2018; http://doi.org/10.7930/NCA4.2018.RiB).

2. C. Phillips, A. Caldas, R. Cleetus, K. A. Dahl, J. Declet-Barreto, R. Licker, L. D. Merner J. P. Ortiz-Partida, A. L. Phelan, E. Spanger-Siegfried, S. Talati, C. H. Trisos, C. J. Carlson, Compound climate risks in the COVID-19 pandemic. Nat. Clim. Chang. 10 586-588 (2020). doi:10.1038/s41558-020-0804-2

3. S. C. Moser, J. A. F. Hart, The long arm of climate change: Societal teleconnections and the future of climate change impacts studies. Clim. Change 129, 13-26 (2015). doi:10.1007/s10584-015-1328-z Medline

4. M. Centeno, M. Nag, T. Patterson, A. Shaver, A. J. Windawi, The Emergence of Global Systemic Risk. Annu. Rev. Sociol. 41, 65-85 (2015). doi:10.1146/annurev-soc073014-112317

5. J. Kania, M. Kramer, P. Senge, "The Water of Systems Change" (FSG, 2018), (available athttps://www.fsg.org/publications/water_of_systems_change).

6. M. Cabaj, L. Weaver, "Collective Impact 3.0: An Evolving Framework for Community Change," Community Change Series (The Tamarack Institute, Waterloo, Canada, 2016), p. 14.

7. J. Fischer, M. Riechers, A leverage points perspective on sustainability. People Nat. 1,115-120 (2019). doi:10.1002/pan3.13

8. A. Smith, 2010-2019: A landmark decade of U.S. billion-dollar weather and climate disasters (National Oceanographic and Atmospheric Administration, Washington, DC, 2020; https://www.climate.gov/news-features/blogs/beyond-data/20102019-landmark-decade-us-billion-dollar-weather-and-climate).

9. A.S.C.E., Infrastructure Report Card: A Comprehensive Assessment of America's Infrastructure (American Society of Civil Engineers, Washington, DC, 2017; https://www.infrastructurereportcard.org).

10. C.S.I.W.G., "Paying It Forward: The Path Toward Climate-Safe Infrastructure in California." (A report by the Climate-Safe Infrastructure Working Group to the California State Legislature and Strategic Growth Council, Sacramento, CA, 2018).

11. L. Shi, A. M. Varuzzo, Surging seas, rising fiscal stress: Exploring municipal fiscal vulnerability to climate change. Cities 100, 102658 (2020). doi:10.1016/i.cities.2020.102658

12. I. Boas, C. Farbotko, H. Adams, H. Sterly, S. Bush, K. van der Geest, H. Wiegel, H. Ashraf, A. Baldwin, G. Bettini, S. Blondin, M. de Bruijn, D. Durand-Delacre, C. Fröhlich, G. Gioli, L. Guaita, E. Hut, F. X. Jarawura, M. Lamers, S. Lietaer, S. L. Nash, E. Piguet, D. Rothe, P. Sakdapolrak, L. Smith, B. Tripathy Furlong, E. Turhan, J. Warner, C. Zickgraf, R. Black, M. Hulme, Climate migration myths. Nat. Clim. Chang. 9, 901-903 (2019). doi:10.1038/s41558-019-0633-3 
13. C. Robinson, B. Dilkina, J. Moreno-Cruz, Modeling migration patterns in the USA under sea level rise. PLOS ONE 15, e0227436 (2020). doi:10.1371/iournal.pone.0227436 Medline

14. M. Hauer, Migration induced by sea-level rise could reshape the US population landscape. Nat. Clim. Chang. 7, 321-325 (2017). doi:10.1038/nclimate3271

15. K. Curtis, J. DeWaard, E. Fussell, R. Rosenfeld, Differential recovery migration across the rural-urban gradient: Minimal and short-term population gains for rural disaster-affected Gulf Coast counties. Rural Sociol. 85, 856-898 (2019). doi:10.1111/ruso.12305

16. A. Cavallo, V. Ireland, Preparing for complex interdependent risks: A System of Systems approach to building disaster resilience. Int. J. Disaster Risk Reduct. 9 181-193 (2014). doi:10.1016/i.i.idrr.2014.05.001

17. A. R. Siders, Adaptive capacity to climate change: A synthesis of concepts, methods, and findings in a fragmented field. Wiley Interdiscip. Rev. Clim. Change 10, e573 (2019). doi:10.1002/wcc. 573

18. J. E. Cinner, W. N. Adger, E. H. Allison, M. L. Barnes, K. Brown, P. J. Cohen, S. Gelcich, C. C. Hicks, T. P. Hughes, J. Lau, N. A. Marshall, T. H. Morrison, Building adaptive capacity to climate change in tropical coastal communities. Nat. Clim. Chang. 8, 117-123 (2018). doi:10.1038/s41558-017-0065-x

19. B. Pfefferbaum, C. S. North, Mental health and the Covid-19 pandemic. N. Engl. J. Med. 383, 510-512 (2020). doi:10.1056/NEJMp2008017 Medline

20. K. T. Aune, D. Gesch, G. S. Smith, A spatial analysis of climate gentrification in Orleans Parish, Louisiana post-Hurricane Katrina. Environ. Res. 185, 109384 (2020). doi:10.1016/i.envres.2020.109384 Medline

21. K. O'Brien, Global environmental change II: From adaptation to deliberate transformation. Prog. Hum. Geogr. 36, 667-676 (2012). doi:10.1177/0309132511425767

22. J. Patterson, K. Schulz, J. Vervoort, S. van der Hel, O. Widerberg, C. Adler, M. Hurlbert, K. Anderton, M. Sethi, A. Barau, Exploring the governance and politics of transformations towards sustainability. Environ. Innov. Soc. Transit. 24, 1-16 (2017). doi:10.1016/i.eist.2016.09.001

23. I. Scoones, A. Stirling, D. Abrol, J. Atela, L. Charli-Joseph, H. Eakin, A. Ely, P. Olsson, L. Pereira, R. Priya, P. van Zwanenberg, L. Yang, Transformations to sustainability: Combining structural, systemic and enabling approaches. Curr. Opin. Environ. Sustain. 42, 65-75 (2020). doi:10.1016/j.cosust.2019.12.004

24. K. P. Henrique, P. Tschakert, Pathways to urban transformation: From dispossession to climate justice. Prog. Hum. Geogr. 10.1177/0309132520962856 (2020). doi:10.1177/0309132520962856

25. M. Pelling, Adaptation to Climate Change: From Resilience to Transformation (Routledge, London, 2010).

26. K. L. O'Brien, S. Eriksen, A. Schjolden, L. Nygaard, What's in a word? Conflicting interpretations of vulnerability in climate change research (2009) (available at http://dspace.cigilibrary.org/jspui/handle/123456789/7304).

27. E. Chu et al., "Unlocking the Potential for Transformative Climate Adaptation in Cities" (Background Paper prepared for the Global Commission on Adaptation, World Resources Institute, Washington, D.C. and Rotterdam, 2019), (available at http://www.gca.org).

28. J. Rodin, The Resilience Dividend: Being Strong in a World Where Things Go Wrong (Public Affairs, New York, 2014).

29. N. Klein, The Shock Doctrine: The Rise of Disaster Capitalism (Alfred A. Knopf Canada, Toronto, 2007).

30. Wretched of the Earth, An open letter to Extinction Rebellion. Red Pepper (2019), (available at https://www.redpepper.org.uk/an-open-letter-to-extinctionrebellion/).

31. S. C. Moser, P. Aldunce, A. Rudnick, M. Rojas, L. Muñoz, "Transformation from science to decision-making." (Policy Brief to COP25, written with support of the COP25 Scientific Committee and the Ministry of Science, Technology, Knowledge and Innovation of Chile, the Economic Commission for Latin America and the Caribbean, the European Union, the Inter-American Development Bank, and the International Science Council, 2019), (available at https://t2sresearch.org/2019/12/19/transformation-from-science-to-decisionmaking).

32. C. L. Berzonsky, S. C. Moser, Becoming homo sapiens sapiens: Mapping the psycho-cultural transformation in the anthropocene. Anthropocene 20, 15-23 (2017). doi:10.1016/j.ancene.2017.11.002
33. C. Ratcliffe, W. J. Congdon, A. Stanczyk, D. Teles, C. Martín, B. Kotapati, Insult to Injury: Natural Disasters and Residents (Urban Insititute, 2019).

34. K. J. Mach, C. M. Kraan, M. Hino, A. R. Siders, E. M. Johnston, C. B. Field, Managed retreat through voluntary buyouts of flood-prone properties. Sci. Adv. 5 , eaax8995 (2019). doi:10.1126/sciadv. aax8995 Medline

35. C. N. A. Corporation, "National Security and the Threat of Climate Change" (CNA Corporation, Alexandria, VA, 2007), p. 35

36. G.A.O., in Report to the Chairman, Select Committee on Energy Independence and Global Warming, House of Representatives (Washington, DC, 2009; https://www.gao.gov/assets/gao-10-113.pdf).

37. V. Kalesnikaite, Keeping Cities Afloat: Climate Change Adaptation and Collaborative Governance at the Local Level. Public Perform. Manag. Rev. 42. 864-888 (2019). doi:10.1080/15309576.2018.1526091

38. A. Schulz, A. Zia, C. Koliba, Adapting bridge infrastructure to climate change: Institutionalizing resilience in intergovernmental transportation planning processes in the Northeastern USA. Mitig. Adapt. Strategies Glob. Change 22. 175-198 (2017). doi:10.1007/s11027-015-9672-x

39. Obama Task Force, President's State, Local, and Tribal Leaders Task Force on Climate Preparedness and Response: Recommendations to the President (The White House, Washington, DC, 2014; https://obamawhitehouse.archives.gov/sites/default/files/docs/task_force_re port_0.pdf)

40. J. M. Keenan, From Climate Change to National Security: Analysis of the Obama Administration's Federal Resilience Mandates and Measures. Nat. Hazards Rev. 19, 04017022 (2018). doi:10.1061/(ASCE)NH.1527-6996.0000273

41. G.A.O., in Statement of J. Alfredo Gómez, Director, Natural Resources and Environment before the Subcommittee on Environment, Committee on Oversight and Reform, House of Representatives (U.S. Government Accountability Office, Washington, DC, 2019; https://www.gao.gov/products/gao-20-338t)

42. D.H.S., National Preparedness Report (Department of Homeland Security, Washington, DC, 2019).

43. C. Flavelle, Trump Administration Presses Cities to Evict Homeowners From Flood Zones, The New York Times (2020), (available at https://www.nytimes.com/2020/03/11/climate/government-land-evictionfloods.html).

44. D. Finn, D. Chandrasekhar, Y. Xiao, A region recovers: Planning for resilience after superstorm Sandy. J. Plann. Educ. Res. 0739456X1986414 (2019). doi:10.1177/0739456X19864145

45. A. Gustafson, S. A. Rosenthal, M. T. Ballew, M. H. Goldberg, P. Bergquist, J. E. Kotcher, E. W. Maibach, A. Leiserowitz, The development of partisan polarization over the Green New Deal. Nat. Clim. Chang. 9, 940-944 (2019). doi:10.1038/s41558-019-0621-7

46. R. Gunn-Wright, R. Hockett, "The Green New Deal," Legal Studies Research Paper Series (Cornell Law School Research Paper 19-09, New Consensus and Cornell University Law School, Ithaca, NY, 2019).

47. J. W. Straka, B. C. Straka, Reframe policymaking dysfunction through bipartisaninclusion leadership. Policy Sci. 53, 1-24 (2020). doi:10.1007/s11077-02009383-2 Medline

48. C. Funk, M. Hefferon, "U.S. Public Views on Climate and Energy" (Pew Research Center Science \& Society, Washington, D.C., 2019), (available at https://www.pewresearch.org/science/2019/11/25/u-s-public-views-onclimate-and-energy/).

49. S. Andrews, A. Selman, in Excerpted from the Proceedings of the 58th Annual Meeting of Invited Attorneys (Victor O. Schinnerer \& Company, Inc, Chevy Chase, MD, 2019)

50. E. Kaplan-Leiserson, High winds of change. PE Magazine (2019) (available at https://www.nspe.org/resources/pe-magazine/may-2019/high-windschange).

51. C.L.F., G.R.C., Climate Adaptation and Liability: A Legal Primer and Workshop Summary Report (Conservation Law Foundation and Boston Green Ribbon Commission, Boston, 2018; https://www.clf.org/wpcontent/uploads/2018/01/GRC_CLF_Report_R8.pdf).

52. Q. Miao, Y. Hou, M. Abrigo, Measuring the Financial Shocks of Natural Disasters: A Panel Study of U.S. States. Natl. Tax J. 71, 11-44 (2018). doi:10.17310/ntj.2018.1.01 
53. Z. A. Conyers, R. Grant, S. Roy, Sea Level Rise in Miami Beach: Vulnerability and Real Estate Exposure. Prof. Geogr. 71, 278-291 (2019). doi:10.1080/00330124.2018.1531037

54. A. Bernstein, M. Gustafson, R. Lewis, Disaster on the Horizon: The Price Effect of Sea Level Rise. J. Financ. Econ. 134, 253-272 (2019). doi:10.1016/i.jineco.2019.03.013

55. S. A. McAlpine, J. R. Porter, Estimating Recent Local Impacts of Sea-Level Rise on Current Real-Estate Losses: A Housing Market Case Study in Miami-Dade, Florida. Popul. Res. Policy Rev. 37, 871-895 (2018). doi:10.1007/s11113-018-9473-5 Medline

56. P. Walsh, C. Griffiths, D. Guignet, H. Klemick, Adaptation, sea level rise, and property prices in the Chesapeake Bay watershed. Land Econ. 95, 19-34 (2019). doi:10.3368/le.95.1.19 Medline

57. C. Kousky, Financing Flood Losses: A Discussion of the National Flood Insurance Program (Resources for the Future, Washington, DC, 2017).

58. UCS, "Underwater: Rising Seas, Chronic Floods, and the Implications for US Coastal Real Estate" (Union of Concerned Scientists, Cambridge, MA, 2018), p. 28.

59. C. Flavelle, D. Lu, V. Penney, N. Popovich, J. Schwartz, New Data Reveals Hidden Flood Risk Across America, The New York Times (2020), (available at https://www.nytimes.com/interactive/2020/06/29/climate/hidden-floodrisk-maps.html).

60. J. M. Keenan, A climate intelligence arms race in financial markets. Science 365 , 1240-1243 (2019). doi:10.1126/science.aay8442 Medline

61. N.G.F.S., A Call for Action: Climate Change as a Source for Financial Risk (Network for Greening the Financial System Secretariat/Banque de France, Paris, 2019).

62. B. Grayson, Moody's: Climate Change Adaptation and Mitigation Could Affect Cities' Bond Ratings. Urban Land (2018), (available at https://urbanland.uli.org/news/moodys-climate-change-adaption-mitigationaffect-cities-bond-ratings/).

63. S.\&P., in Global Ratings, Poor, Ed. (Standard, New York, 2019; https://www.spratings.com/en_US/products/-/product-detail/our-approachtoesg-in-ratings.).

64. W.F.E.O., Model Code of Practice: Principles of Climate Change Adaptation for Engineers. World Federation of Engineering Organizations (2015) (available at https://www.wfeo.org/wp-content/uploads/code-of-

practice/WFEO_Model_Code_of_Practice_Principles_Climate_Change_Adaptati on_Engineers.pdf).

65. B. Ayyub, Ed., in Committee on Adaptation to a Changing Climate (American Society of Civil Engineers, Washington, DC, 2018; https://ascelibrary.org/doi/book/10.1061/9780784415191).

66. P. Bigger, N. Millington, Getting soaked? Climate crisis, adaptation finance, and racialized austerity. Environ. Planning E Nat. Space 3, 601-623 (2019). doi:10.1177/2514848619876539

67. J. M. Keenan, J. T. Bradt, Underwaterwriting: From theory to empiricism in regional mortgage markets in the U.S. Clim. Change 162, 2043-2067 (2020). doi:10.1007/s10584-020-02734-1

68. Z. J. Taylor, J. L. Weinkle, The riskscapes of re/insurance. Camb. J. Regions Econ. Soc. 13, 405-422 (2020). doi:10.1093/cires/rsaa015

69. S. Woodruff, T. BenDor, A. Strong, Fighting the inevitable: Infrastructure investment and coastal community adaptation to sea level rise. Syst. Dyn. Rev. 34, 48-77 (2018). doi:10.1002/sdr.1597

70. M. Garcia-Lamarca, I. Anguelovski, H. Cole, J. J. T. Connolly, L. Argüelles, F. Baró, S. Loveless, C. Pérez del Pulgar Frowein, G. Shokry, Urban green boosterism and city affordability: For whom is the 'branded' green city? Urban Stud. 58, 90-112 (2019). doi:10.1177/0042098019885330

71. V. Eubanks, My Drowning City Is a Harbinger of Climate Slums to Come. The Nation (2016), (available at https://www.thenation.com/article/low-water-mark/).

72. G. Shokry, J. J. Connolly, I. Anguelovski, Understanding climate gentrification and shifting landscapes of protection and vulnerability in green resilient Philadelphia. Urban Climate 31, 100539 (2020). doi:10.1016/i.uclim.2019.100539

73. E. Nance, Flood Buyout Inequity in Greater Houston (2020).

74. J. M. Keenan, T. Hill, A. Gumber, Climate gentrification: From theory to empiricism in Miami-Dade County, Florida. Environ. Res. Lett. 13, 054001 (2018). doi:10.1088/1748-9326/aabb32
75. J. K. Maldonado, B. Colombi, R. Pandya, Eds., Climate Change and Indigenous Peoples in the United States: Impacts, Experiences and Actions (Springer International Publishing, Cham, 2014; http://link.springer.com/10.1007/978-3319-05266-3)

76. R. Bronen, F. S. Chapin 3rd, Adaptive governance and institutional strategies for climate-induced community relocations in Alaska. Proc. Natl. Acad. Sci. U.S.A. 110, 9320-9325 (2013). doi:10.1073/pnas.1210508110 Medline

77. I. Anguelovski, L. Shi, E. Chu, D. Gallagher, K. Goh, Z. Lamb, K. Reeve, H. Teicher, Equity impacts of urban land use planning for climate adaptation: Critical perspectives from the global north and south. J. Plann. Educ. Res. 36, 333-348 (2016). doi:10.1177/0739456X16645166

78. L. Shi, From progressive cities to resilient cities: Lessons from history for new debates in equitable adaptation to climate change. Urban Aff. Rev. 10.1177/1078087419910827 (2020). doi:10.1177/1078087419910827

79. E. Marino, Adaptation privilege and Voluntary Buyouts: Perspectives on ethnocentrism in sea level rise relocation and retreat policies in the US. Glob. Environ. Change 49, 10-13 (2018). doi:10.1016/j.gloenvcha.2018.01.002

80. E. Torabi, A. Dedekorkut-Howes, M. Howes, Adapting or maladapting: Building resilience to climate-related disasters in coastal cities. Cities 72, 295-309 (2018). doi:10.1016/i.cities.2017.09.008

81. A. K. Magnan, E. L. F. Schipper, M. Burkett, S. Bharwani, I. Burton, S. Eriksen, F. Gemenne, J. Schaar, G. Ziervogel, Addressing the risk of maladaptation to climate change. Wiley Interdiscip. Rev. Clim. Change 7, 646-665 (2016). doi:10.1002/wcc. 409

82. V. C. Broto, E. Robin, A. While, Eds., Climate Urbanism: Towards a Critical Research Agenda (Palgrave Macmillan, 2020; https://www.palgrave.com/gp/book/9783030533854)

83. B. P. Warner, C. P. Kuzdas, The role of political economy in framing and producing transformative adaptation. Curr. Opin. Environ. Sustain. 29, 69-74 (2017). doi:10.1016/i.cosust.2017.12.012

84. F.-A. Hoover, T. C. Lim, Examining privilege and power in US urban parks and open space during the double crises of antiblack racism and COVID-19. Socio. Ecol. Pract. Res. 10.1007/s42532-020-00070-3 (2020)

85. A. Kothari, F. Demaria, A. Acosta, Buen Vivir, Degrowth and Ecological Swaraj: Alternatives to sustainable development and the Green Economy. Development 57, 362-375 (2014). doi:10.1057/dev.2015.24

86. NAACP, "Equity in Building Resilience in Adaptation Planning" (National Association for the Advancement of Colored People (NAACP), Baltimore, MD, 2015).

87. APEN, "Mapping Resilience: A Blueprint for Thriving in the Face of Climate Disasters" (Asian Pacific Environmental Network, Oakland, CA, 2019).

88. N. Fraser, Recognition or Redistribution? A Critical Reading of Iris Young's Justice and the Politics of Difference*. J. Polit. Philos. 3, 166-180 (1995). doi:10.1111/i.1467-9760.1995.tb00033.x

89. S. Woodruff, M. Stults, Numerous strategies but limited implementation guidance in US local adaptation plans. Nat. Clim. Chang. 6, 796-802 (2016). doi:10.1038/nclimate3012

90. E. D. Mondainé, M. Lee, Beyond Theory: Climate Justice in Practice. Buildings and Cities (2020) (available at https://www.buildingsandcities.org/insights/commentaries/beyond-theoryclimate-justice-practice.html).

91. Climate Justice Alliance, Climate Justice Alliance, (available at https://climatejusticealliance.org/).

92. K. P. Whyte, J. P. Brewer II, J. T. Johnson, Weaving Indigenous science, protocols and sustainability science. Sustain. Sci. 11, 25-32 (2016). doi:10.1007/s11625015-0296-6

93. M. Ranganathan, E. Bratman, Antipode 10.1111/anti.12555 (2019).

94. S. C. Moser, J. Coffee, A. Seville, "Rising to the Challenge, Together: A Review and Critical Assessment of the State of the US Climate Adaptation Field" (Kresge Foundation, Troy, MI, 2017).

95. R. W. Kates, W. R. Travis, T. J. Wilbanks, Transformational adaptation when incremental adaptations to climate change are insufficient. Proc. Natl. Acad. Sci. U.S.A. 109, 7156-7161 (2012). doi:10.1073/pnas.1115521109 Medline 
96. V. Gallina, S. Torresan, A. Critto, A. Sperotto, T. Glade, A. Marcomini, A review of multi-risk methodologies for natural hazards: Consequences and challenges for a climate change impact assessment. J. Environ. Manage. 168, 123-132 (2016). doi:10.1016/i.jenvman.2015.11.011 Medline

97. L. Shi, Promise and paradox of metropolitan regional climate adaptation. Environ. Sci. Policy 92, 262-274 (2019). doi:10.1016/i.envsci.2018.11.002

98. J. Zscheischler, S. Westra, B. J. J. M. van den Hurk, S. I. Seneviratne, P. J. Ward, A. Pitman, A. AghaKouchak, D. N. Bresch, M. Leonard, T. Wahl, X. Zhang, Future climate risk from compound events. Nat. Clim. Chang. 8, 469-477 (2018). doi:10.1038/s41558-018-0156-3

99. H. R. Moftakhari, G. Salvadori, A. AghaKouchak, B. F. Sanders, R. A. Matthew, Compounding effects of sea level rise and fluvial flooding. Proc. Natl. Acad. Sci. U.S.A. 114, 9785-9790 (2017). doi:10.1073/pnas.1620325114 Medline

100. FEMA, "Building Community Resilience with Nature-Based Solutions: A Guide for Local Communities" (Federal Emergency Management Agency. Washington, D.C., 2020), (available at https://www.fema.gov/sites/default/files/202007/fema_bric_nature-based-solutions-guide_2020.pdf).

101. J. J. Opperman, "A Flood of Benefits: Using Green Infrastructure to Reduce Flood Risks" (The Nature Conservancy, Arlington, VA, 2014), (available at https://www.conservationgateway.org/ConservationPractices/Freshwater/Ha bitatProtectionandRestoration/Documents/A\%20Flood\%20of\%20Benefits\%2 0-\%20J.Opperman\%20-\%20May\%202014.pdf).

102. L. Shi, Beyond flood risk reduction: How can green infrastructure advance both social justice and regional impact? Socio. Ecol. Pract. Res. 2, 311-320 (2020). doi:10.1007/s42532-020-00065-0

103. J. L. MacArthur, C. E. Hoicka, H. Castleden, R. Das, J. Lieu, Canada's Green New Deal: Forging the socio-political foundations of climate resilient infrastructure? Energy Res. Soc. Sci. 65, 101442 (2020). doi:10.1016/j.erss.2020.101442

104. R. Galvin, N. Healy, The Green New Deal in the United States: What it is and how to pay for it. Energy Res. Soc. Sci. 67, 101529 (2020). doi:10.1016/i.erss.2020.101529

105. P. Tschakert, B. van Oort, A. L. St. Clair, A. LaMadrid, Inequality and transformation analyses: A complementary lens for addressing vulnerability to climate change. Clim. Dev. 5, 340-350 (2013). doi:10.1080/17565529.2013.828583

106. A. R. Siders, Social justice implications of US managed retreat buyout programs Clim. Change 152, 239-257 (2019). doi:10.1007/s10584-018-2272-5

107. G. Owen, What makes climate change adaptation effective? A systematic review of the literature. Glob. Environ. Change 62, 102071 (2020). doi:10.1016/igloenvcha.2020.102071

108. J. T. Malloy, C. M. Ashcraft, A framework for implementing socially just climate adaptation. Clim. Change 160, 1-14 (2020). doi:10.1007/s10584-020-02705-6

109. N. Suckall, E. L. Tompkins, K. Vincent, A framework to analyse the implications of coastal transformation on inclusive development. Environ. Sci. Policy 96, 64-69 (2019). doi:10.1016/i.envsci.2019.03.003

110. J. Klein, M. Araos, A. Karimo, M. Heikkinen, T. Ylä-Anttila, S. Juhola, The role of the private sector and citizens in urban climate change adaptation: Evidence from a global assessment of large cities. Glob. Environ. Change 53, 127-136 (2018). doi:10.1016/i.gloenvcha.2018.09.012

111. S. Juhola, E. Glaas, B.-O. Linnér, T.-S. Neset, Redefining maladaptation. Environ. Sci. Policy 55, 135-140 (2016). doi:10.1016/i.envsci.2015.09.014

112. G. Zuccaro, D. De Gregorio, M. Leone, Theoretical model for cascading effects analyses. Int. J. Disaster Risk Reduct. 30, 199-215 (2018). doi:10.1016/i.ijdrr.2018.04.019

113. I. Anguelovski, J. J. T. Connolly, H. Pearsall, G. Shokry, M. Checker, J. Maantay, K. Gould, T. Lewis, A. Maroko, J. T. Roberts, Opinion: Why green "climate gentrification" threatens poor and vulnerable populations. Proc. Natl. Acad. Sci. U.S.A. 116, 26139-26143 (2019). doi:10.1073/pnas.1920490117

114. I. Overland, B. Sovacool, The misallocation of climate research funding. Energy Res. Soc. Sci. 62, 101349 (2020). doi:10.1016/j.erss.2019.101349

115. J. M. Melillo, T. Richmond, G. W. Yohe, Eds., Climate Change Impacts in the United States: The Third U.S. National Climate Assessment (U.S. Global Change Research Program, Washington, D.C., 2014; http://purl.fdlp.gov/GPO/gpo48682).

116. R. Bromley-Trujillo, M. R. Holman, Climate Change Policymaking in the States: A View at 2020. Publius 50, 446-472 (2020). doi:10.1093/publius/pjaa008
117. R. E. Boyatzis, K. Thiel, K. Rochford, A. Black, Emotional and social intelligence competencies of incident team commanders fighting wildfires. J. Appl. Behav. Sci. 53, 498-516 (2017). doi:10.1177/0021886317731575

118. D. Gilford, S. C. Moser, B. DePodwin, R. Moulton, S. Watson, The emotional toll of climate change on science professionals. Eos 100, 6 (2019). doi:10.1029/2019E0137460

119. D. Pruneau, J. Kerry, S. Blain, E. Evichnevetski, P. Deguire, P.-Y. Barbier, V. Freiman, J. Therrien, J. Langis, M. Lang, Competencies demonstrated by municipal employees during adaptation to climate change: A pilot study. J. Environ. Educ. 44, 217-231 (2013). doi:10.1080/00958964.2012.759521

120. P. Cianconi, S. Betrò, L. Janiri, The Impact of Climate Change on Mental Health: A Systematic Descriptive Review. Front. Psychiatry 11, 74 (2020). doi:10.3389/fpsyt.2020.00074 Medline

121. K. Raworth, A Doughnut for the Anthropocene: Humanity's compass in the 21st century. Lancet Planet. Health 1, e48-e49 (2017). doi:10.1016/S25425196(17)30028-1 Medline

122. G. Kallis, V. Kostakis, S. Lange, B. Muraca, S. Paulson, M. Schmelzer, Research On Degrowth. Annu. Rev. Environ. Resour. 43, 291-316 (2018). doi:10.1146/annurev-environ-102017-025941

123. I. M. Algunaibet, C. Pozo, Á. Galán-Martín, M. A. J. Huijbregts, N. Mac Dowell, G. Guillén-Gosálbez, Powering sustainable development within planetary boundaries. Energy Environ. Sci. 12, 1890-1900 (2019). doi:10.1039/C8EE03423K Medline

124. S. C. Moser, Science for the Speed-up: Quo vadis Science-Society Interactions in a Climate Changed World? AGU Annual Meeting, San Francisco (2019).

125. I. Fazey et al., Transforming knowledge systems for life on Earth: Visions of future systems and how to get there. Energy Res. Soc. Sci. 70, 101724 (2020) doi:10.1016/i.erss.2020.101724

\section{ACKNOWLEDGMENTS}

We are grateful to two anonymous reviewers for their feedback on an earlier draft. Funding: This Review was not part of funded research. Author contributions: All authors contributed equally to the paper's conceptualization, L.S. led the writing of the initial draft, while S.M. led the recasting of the revised draft. L.S. and S.M. contributed equally to implementing necessary edits and revisions. Competing Interests: The authors have no conflicts of interest. Data and materials availability: All documents reviewed are available online.

8 June 2020; accepted 20 April 2021

Published online 29 April 2021

10.1126/science.abc8054 


\section{Transformation: Shifting the Conditions that Hold Systems in Place}

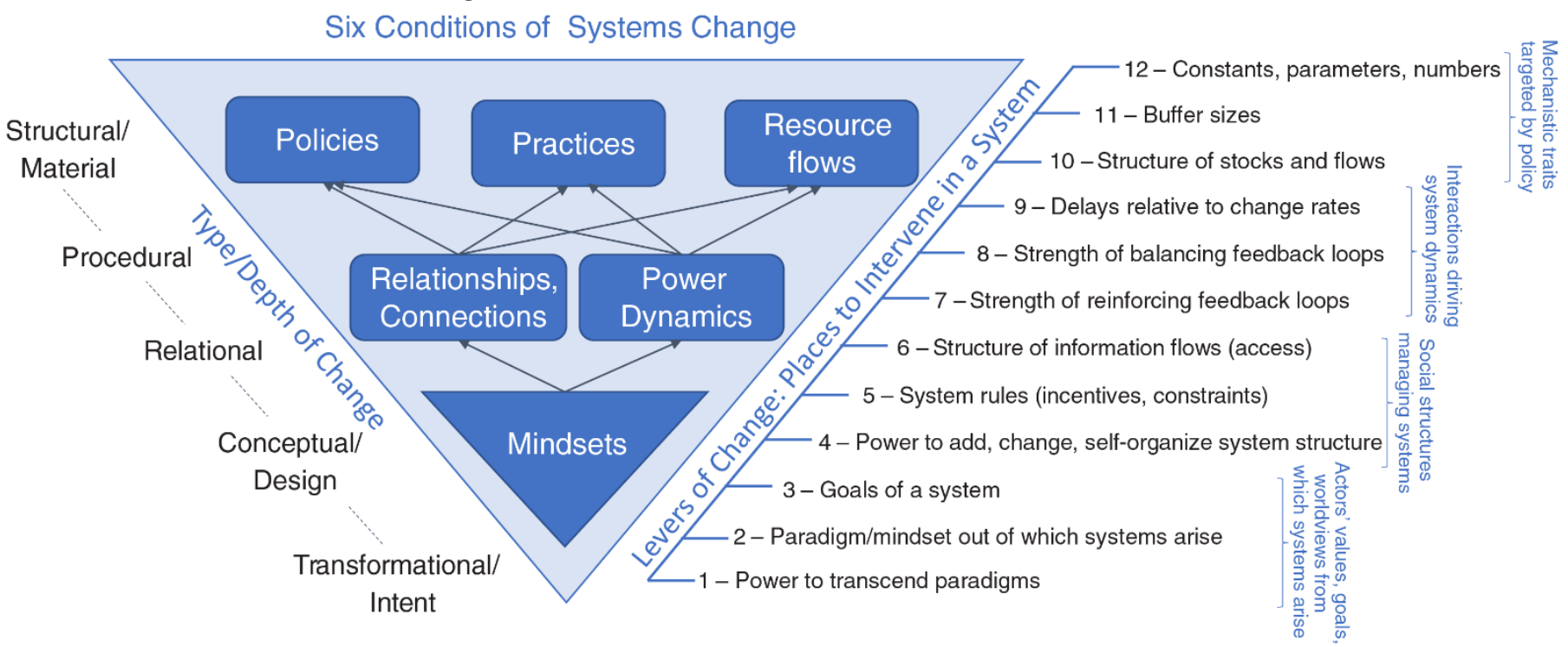

Fig. 1. Six conditions of transformative systems change. Systems are shaped by surface level, policies, practices and resource flows, which in turn are driven by relationships and power dynamics among those making decisions, which in turn reflects stakeholders' mindsets, values and beliefs (depicted by triangles). Transformative change of material outcomes stems from changing the intent and conceptual, relational and procedural conditions driving systems (left side of diagram). Levers to create change range from altering the structure of stocks and flows at more superficial levels, to changing incentives and constraints at deeper levels, to changing system goals and mindsets (right side of diagram). [Reprinted with permission from (31)] 


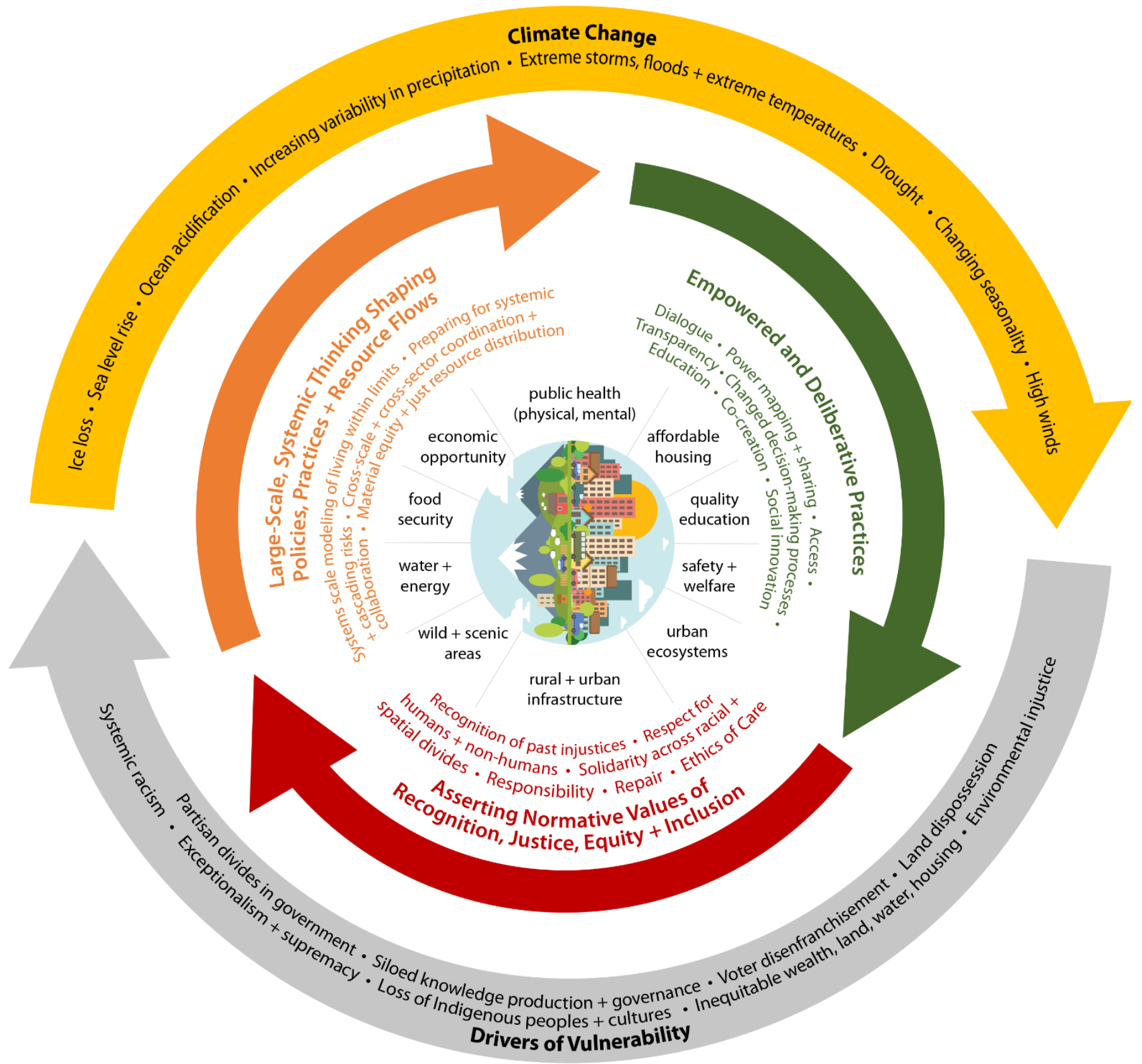

Fig. 2. Framework for transformative adaptation. Transformative adaptation needs to respond to the magnitude of climate risks (yellow arrow) by addressing root drivers of vulnerability (grey arrow). Large scale, systemic thinking is necessary to coordinate adaptation across scales, sectors, and hazards (orange arrow). Such societal mobilization requires both deep deliberation across silos (green arrow), and an assertion of normative values of justice and equity (red arrow) so that large-scale actions do not repeat racist, inequitable, and unsustainable outcomes. Transformative thinking at all three levels (material, relational, mindset) is needed in all areas shaping societal well-being and across urban-rural landscapes. [Original graphic by the authors] 
Table 1. Shifts in federal policy regarding climate adaptation under the Obama and Trump administrations. While the Biden Administration has taken steps to revoke several Trump climate policies, domestic policy proposals for adaptation have not yet coalesced into a coherent approach.

\begin{tabular}{|c|c|}
\hline Obama administration & Trump administration \\
\hline $\begin{array}{l}\text { Preparing the United States for the Impacts of Climate } \\
\text { Change (Executive Order 13563, 2013) and Climate Action Plan } \\
\text { (2013) required federal agencies to submit resilience plans to } \\
\text { the White House Council on Environmental Quality (CEQ) and } \\
\text { Office of Management and Budget (OMB) }\end{array}$ & $\begin{array}{l}\text { Revoked by Promoting Energy In- } \\
\text { dependence and Economic Growth } \\
\text { (Executive Order 13783, 2017) }\end{array}$ \\
\hline $\begin{array}{l}\text { Planning for Federal Sustainability in the Next Decade (Ex- } \\
\text { ecutive Order 13693, 2015) required interagency working } \\
\text { groups to form and coordinate resilience planning with other } \\
\text { levels of government and stakeholders; OMB to review agen- } \\
\text { cies' sustainability performance; and Office of Personnel Man- } \\
\text { agement to train federal staff on resilience. }\end{array}$ & $\begin{array}{l}\text { Revoked by Efficient Federal Op- } \\
\text { erations (Executive Order 13834, } \\
\text { 2018) }\end{array}$ \\
\hline $\begin{array}{l}\text { Establishing a Federal Flood Risk Management Standard } \\
\text { and a Process for Further Soliciting and Considering Stake- } \\
\text { holder Input (Executive Order 13690, 2015) tasked federal agen- } \\
\text { cies to consider climate science as part of all federal planning } \\
\text { for facilities and programs for floods. }\end{array}$ & $\begin{array}{l}\text { Revoked by Establishing Disci- } \\
\text { pline and Accountability in the Envi- } \\
\text { ronmental Review and Permitting } \\
\text { Process for Infrastructure Projects } \\
\text { (Executive Order 13807, 2017) }\end{array}$ \\
\hline $\begin{array}{l}\text { FEMA's Climate Change Adaptation Policy required federal } \\
\text { (starting in 2012) and state (2015) programs and policies to ac- } \\
\text { count for climate impacts; General Services Administration's } \\
2016 \text { Guiding Principles Checklist (P100) for new construction } \\
\text { or major renovation requires consideration of climate change }\end{array}$ & $\begin{array}{l}\text { Proposed } 2020 \text { amendment to the } \\
\text { National Environmental Policy Act } \\
\text { would absolve federal agencies from } \\
\text { accounting for climate impacts in in- } \\
\text { frastructure proposals }\end{array}$ \\
\hline
\end{tabular}

